\title{
メチルメタクリレートートリメチロールプロパントリメタクリレート共重合系の ゲル化における溶媒効果
}

\author{
松本 昭*1 $・$ 安藤博之*1 $・$ 大岩 正芳*1
}

（受付 1989 年 5 月 30 日・審查終了 1989 年 7 月 3 日）

\begin{abstract}
要 旨メチルメタクリレートとトリメチロールプロパントリメタクリレート (TMPMA) のラジカル共重合

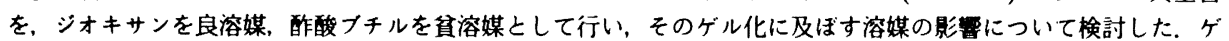
儿化点の実測値の理論値からのずれは概して良溶媒中の方が大きく，分子間橋かけ反応に対する排除体積勃果の重 要性が示唆された。しかしながら，高希釈系で，かつ橋かけ骫である TMPMA 仕込み量の少ない系では，逆に算溶 媒中の方がゲル化が荤延した．これは分子内橋かけ反応が生起しやすい結果, 橋かけに有効なペンタントビ二ル基 がフレポリマー中に不足することによると推察された。また，一次ポリマー銷中の大環状構造の形成は筫溶媒中の 方か促進された。
\end{abstract}

\section{1 粕言}

多官能ビニルモノマーのゲル化に関する研究の歴史は 大変古いにもかかわらず，その機構が非常に複雑であ るため未だ十分に解明されたとは言いにくく，現在活発 にその基礎研究が展開されている゙。 なかでも, ジビ ニルヘンぜン2) 10), エチレンジメタクリレート

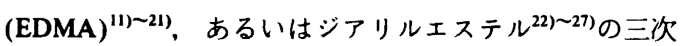
元化機構に関する報告が数多くなされている.

著者らは従来より多官能ビニルモノマーの三次元化機 構に関する一連の研究を展開しており, ジアリルエステ ルのラジカル重合におけるゲル化をまず取り上げた。こ の重合系では, 一次ポリマー鎖長が短くゲル化点が塊状 重合でも約 25\% と高重合率側にあるため,ゲル化に至 るまでの過程を追跡する上で実験的に多くの情報が得ら れやすい特徴がある。 そこで，モノマー及びプレポリ マーの単独重合あるいは共重合における溶媒効果 28 ) 30), 分子量分布の経時変化の GPC による追跡 ${ }^{26), 31}$ 重合系中 に生成するプレポリマーの溶液物性の光散乱測定及び極 限粘度からの検討 ${ }^{28), 29)}$ といった面から研究した結果, ゲ ル化の遅れに対する重要な要因の一つとして，これまで

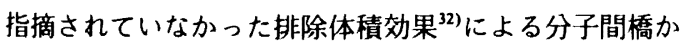
け反応の抑制を考慮すべきであることを提案した299. す なわち、ジアリルエステルの実測ゲル化点が Gordon の 式到を用いて算出した理論ゲル化点の 4〜6倍と大きく 高重合率倒へずれることを明らかにし 26), このようなゲ ル化の遅れに対して従来より指摘されている，i）環化, ii) プレポリマー中の二重合結合の反応性の低下, iii) 分

\footnotetext{
*1 関西大学工学部応用化学科 (テ564 吹田市山手町 3-3-35)
}

子内橋かけ(多重橋かけ),iv) ミクロゲル形成などの諸因 子について逐一検討した．環化を考慮したGordonの式 を用いても理論ゲル化点と実測值のずれは大きいこと， プレポリマー中のペンダントビニル基の反応性がモ， マーに比してほとんど低下していないこと吕，加えて理 論ゲル化点（フタル酸ジアリルの塊状重合では 5.5\%) ${ }^{26)}$ 付近でのプレポリマーでは高度に分子内橋かけしたよう すむなく（高度の分子内橋かけ，すなわち多重橋かけは ミクロゲル形成をもたらす年〜 16)，またその分子量分布 あかなり狭いところから，上記の諸因子だけではゲル化 の遅れを説明するには不十分であり, 重合初期段階での プレポリマー間の反応に対する排除体積効果の寄与が推 察された. すなわち、ジアリルフタレートプレポリマー の良溶媒中での後重合において, 高分子量化したポリ マー間に動的排除体積効果が作用してポリマー鎖の相互 侵入が抑制される結果, 分子間橋かけ反応が抑制され だ28 ように，モ/マーがプレポリマーに対して良溶媒で あることを考慮すると, 重合初期段階ではプレポリマー の間の反応, 特に高分子量プレポリマー間の分子間橋か け反応の抑制に対する排除体積効果の寄与が示唆され た. なお，この排除体積効果は重合が進むにつれ，換言 すればプレポリマー濃度の增大とともに減殺されること になる.

ところで，このような排除体積効果はゲル化に対する 溶媒効果としてより直接的に反映されることが考えられ る. すなわち, 良溶媒中でのゲル化は貞溶媒中に比べて 排除体積効果のため遅延されることが推察される。しか るに, Walling"1) はメチルメタクリレート (MMA) と EDMA の共重合におけるゲル化について詳細に研究し た際, 上記の推察とは逆に貧溶媒中ほどゲル化が遅れる 
と報告している.なお，Walling の実験では，ゲル化点は 系の流動性の変化加間接的に求められており, 一次ポ リマー鎖長も MMA ホモポリマーの粘度測定から決定 された。そこで, MMA-EDMA 共重合系のゲル化にお ける溶媒効果を詳細に再検討したところ，ゲル化点, 一 次鎖長共にかなり高く得られ, 予想どおり明らかに良溶

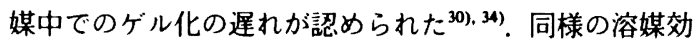
果が MMA とオリゴグリコールジメタクリレートの共 重合においても観察された ${ }^{35}$.

著者らは多官能ビニルモノマーのゲル化に関する一連 の研究の展開として MMA とトリメチロールプロパン トリメタクリレート (TMPMA) の共重合を取り上げ, モノビニルートリビニル共重合系のゲル化挙動を詳細に 検討した。 MMA-EDMA 共重合系との対比については 前報 ${ }^{36)} て ゙$ 明らかにしたので, 本報では溶媒効果について 考察する．すなわち，上述の分子間橋かけ反応に対する 排除体積効果に加え，分子内橋加け反応に対する溶媒効 果の重要性を明らかにした。

\section{2 実験}

2.1 試薬

MMA, 開始戍の 2,2'-アゾビスイソブチロニトリル (AIBN), 溶媒の 1,4 ジオキサン (DOx) 及び酶酸 $n$-ブチ ル (BuAc) は常法に従って精製した. TMPMA は共栄社 油脂化学工業(株)から提供されたものをそのまま用い た.

\section{2 重合}

重合は通常の封管法によって行った，所定時間重合 後, 重合液を約 20 倍量のメタノール中に注ぎ込み, ポリ マーを析出させた，得られたポリマーをメタノールで繰 り返し洗浄後, 恒量に達するまで減圧乾燥して重合率を 求めた.

\section{3 ソルとゲルの分略}

ゾルとゲルの分離はTHF を抽出溶媒として行った. すなわち，上記のようにして回収したゾルを含むゲル化 ポリマーを遠沈管に秤取し，大過剩の THF で十分に膨 潤させ，ゲルを遠心分離する．上澄液を除去した後， THF を新たに加えて膨潤ゲルを十分に洗浄し，再度遠 心分離する．上澄液にゾルが溶出しなくなるまでこの操 作を 3〜4回繰り返した。最後に膨潤ゲルをメタノール で処理し，ゲル中の THFをメタノールで置換した後, 减圧乾操してゲル含量を求めた。

\section{4 測定}

プレポリマーの重量平均分子量 $\overline{\boldsymbol{M}}_{w}$ は光散乱法によっ た.すなわち，ユニオン技研(株)製 LS-601 型光散乱光度 計を用い, THF 中, $30 \pm 0.1^{\circ} \mathrm{C}$, 測定角度 $30 \sim 150^{\circ}, \mathrm{He}-$ $\mathrm{Ne}$ レーザー（波長 $632.8 \mathrm{~nm}$ ）を光源として測定した.

プレポリマーの極限粘度は, ウベローデ型粘度計を用
い，THF 中， $30^{\circ} \mathrm{C}$ で測定した。

GPC-LALLS 測定は，Waters 社製 ALC/GPC244 型装 置を用い, 5 本力ラム組合せ（東ソー(株)製 $\mathrm{G}^{2} 2000 \mathrm{H}_{6}$, $\mathrm{G}^{2} 3000 \mathrm{H}_{6}, \mathrm{G}_{4000 \mathrm{H}_{6}}, \mathrm{G} 5000 \mathrm{H}_{6}, \mathrm{G} 6000 \mathrm{H}_{6}$ ), 流速 $1 \mathrm{ml} / \mathrm{min}$, 試料濃度 $0.2 \%(\mathrm{w} / \mathrm{v})$, 室温にて, THF を溶離液として 行った。なお, 検出器として示差屈折計及び低角度レー ザー光散乱光度計（LALLS，東ソー(株)製 LS-8000）を 直列に用い, 同時検出を行った。

ゲルの膨潤比は次のようにして求めた。すすなわち，お らかじめ精秤した $\left(W_{0}\right)$ 遠沈管にゲルを適量採取し, THF を十分に加えて膨潤平衝に達するまで室温で静置 した，その後，遠心分離によって上澄液を除去し，さら にろ紙上に膨潤ゲルをひろげた後, 速やかに遠沈管にゲ ルを戻し, 秤量した $\left(W_{1}\right)$. ついで, ゲル中の THFをメ タノールで置換した後, 恒量に達するまで減圧乾燥し, 精秤した $\left(W_{2}\right)$.

膨潤比 $=\left(W_{1}-W_{0}\right) /\left(W_{2}-W_{0}\right)$

\section{3 結果及ひ考察}

\subsection{TMPMA 橋かけ棰造単位}

MMA-TMPMA コポリマー中の TMPMA 単位の構造 としては次の 2 種が考えられる.なお，ビシクロ環構造 の形成については分子模型による検討から無視できると 思われる ${ }^{36)}$. すなわち， 2 個のペンダントビニル基をむ つ未環状単位 (I) と 1 個のペンダントビニル基をむつモ ノシクロ環状単位 (II) がコポリマー中に導入され, これ らが橋かけ単位として作用し、ゲル化をもたらすことに なる. 換言すれば, TMPMA 単位がポリマー中に導入さ れれば必然的に橋かけに有効なビニル基が導入されるこ<smiles>C=C(C)C(=O)OCC(CC)(COC(=O)C(=C)C)COC(=O)C(C)CC</smiles>

高分子論文集, Vol. 46, No. 10 (1989) 


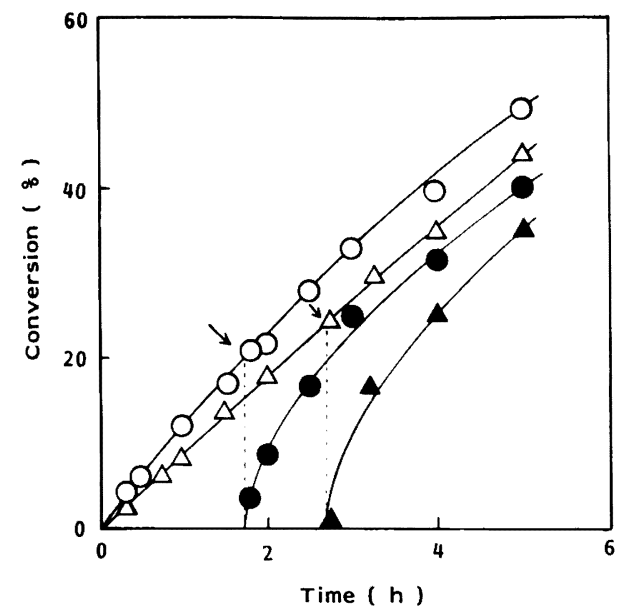

Fig. 1. Time conversion curves for the MMATMPMA (99:1) copolymerization in 1,4-dioxane $(O)$ and $n$-butyl acetate $(\triangle): \bigcirc, \triangle$, total polymer; $\odot$, $\Delta$, gel polymer; $(\downarrow)$ gel point. Polymerizations were conducted in a dilution of $1 / 5$ using $0.04 \mathrm{~mol} / \mathrm{l}$ of AIBN at $50^{\circ} \mathrm{C}$.

とになる.なお, I は 2 個のビニル基を有するものの，そ の一方が橋かけ反応に関与すれば，立体障害のために他 方は橋かけ反応を受けないと推定され，したがって TMPMA はジビニルモノマーと類似の橋かけ挙動を示 すと考えられる. 実際に, I と II の割合については, 環 化重合の観点から先に詳細な検討を行っており ${ }^{36)}$, 本研 究における重合条件下では 73〜88\% が II のモノシクロ 環構造であると算出される.

\section{2 ゲル化点の決定}

既報 ${ }^{35)}$ と同様，生成ポリマーの光散乱及び極限粘度測 定の結果に基づき, DOx を良溶媒, BuAc を貣溶媒とし て選定した。

MMA と TMPMA の共重合は, $[\mathrm{AIBN}]=0.04 \mathrm{~mol} / l$, $50^{\circ} \mathrm{C}$ と一定にし, TMPMA 仕込み量を $0.5,1,1.5$, 及び $5 \mathrm{~mol} \%$ と変え, $1 / 3,1 / 5$, 及び $1 / 8$ 希釈系にて行った.

Fig. 1 には, TMPMA 仕込み量 $1 \mathrm{~mol} \%, 1 / 5$ 希釈系での 重合結果を一例として示した。重合速度は DOx 中で若 干速くなっており，またゲル効果は認められなかった.

ゲル化点の決定は外挿法によった. すなわち，ゲル生 成曲線を外挿することによって系中にゲルが生成し始め る時間を求め, その時間での重合率をもってゲル化点と した. Fig. 1 では DOx 中で $21 \%$, BuAc 中で $24 \%$ と求め られ，見掛け上負溶媒中でゲル化が遅延された。これと 同様の結果は既報 ${ }^{35)}$ の MMA とオリゴグリコールジメ タクリレートの共重合において観察されており, 同時に 生成ポリマーの分子量あ大きく異なるものであった．こ

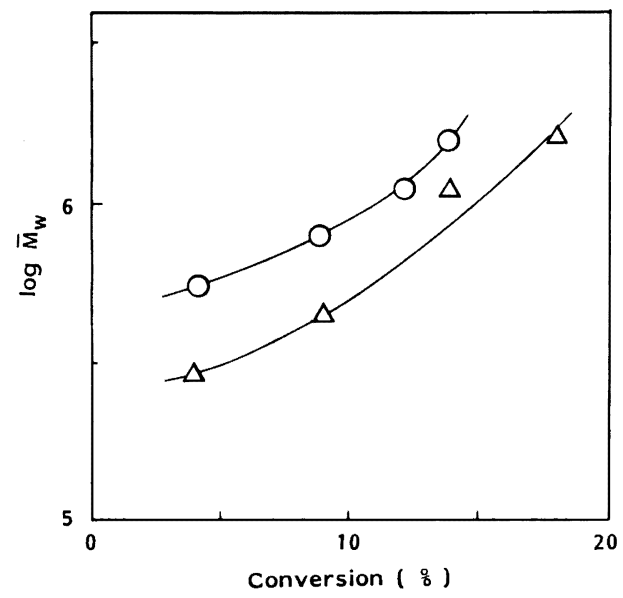

Fig. 2. Dependence of $\bar{M}_{w}$ on conversion in the MMA-TMPMA $(99: 1)$ copolymerization in 1,4dioxane $(O)$ and $n$-butyl acetate $(\triangle)$. Polymerization conditions were the same as those in Fig. 1.

の分子量に及ぼす溶媒効果については, 大環状構造の形 成を伴う分子内環化反応の生起のしやすさに対する溶媒 効果の反映であることが明らかにされている. 一方, 本 研究で取り上げた MMA と TMPMA の共重合において あ同様の分子内環化反応がかなり生起することが前報 ${ }^{36)}$ で明らかになっており，そこで次に生成ポリマーの分子 量測定を試みた。 なお，ゲル化を議論する上で分子量が 重要な因子であることは言うまでもない.

\section{3 一次ポリマー鎖長}

Fig. 2 は生成ポリマーの重量平均分子量 $\bar{M}_{w}$ の重合率 依存性を示したものである. 重合率の増大とともに $\bar{M}_{w}$ が大きくなっており，これは重合の進行とともに橋かけ 反応の生起が活発化していることを示唆している。 た， $\bar{M}_{w}$ は良溶媒である DOx 中で生成したポリマーの方 が貣溶媒である BuAc 中に比してかなり大きくなってい るのがわかる. この良溶媒中での $\bar{M}_{w}$ の增大は, 先に MMA とオリゴグリコールジメタクリレートの共重合に おいて考察したように, 大環状構造の形成に伴う 2 分子 停止の遅れと関連しているものと考えられる.この点に ついては後にもう少し詳しく考察する.

Fig. 2 において, 重合率ゼロに外㨉することによって 一次ポリマー鎖の分子量 $\bar{M}_{\mathrm{w}, 0}$ が求められ, DOx 中で $4.57 \times 10^{5}, \mathrm{BuAc}$ 中で $2.58 \times 10^{5}$ となった. 見掛け上, DOx 中でゲル化が促進されたのはこの分子量の大きな 違いと関連していると考えられる.すなわち, ゲル化に おける溶媒効果を議論する際, 一次ポリマー鎖の分子量 が溶媒によって大きく異なる場合にはゲル化点の実測値 を直接比較してもあまり意味のないことになる．そこ 
Table 1. Gelation in the copolymerization of methyl methacrylate with trimethylolpropane trimethacrylate (TMPMA)

\begin{tabular}{|c|c|c|c|c|c|}
\hline \multirow{2}{*}{ Solvent ${ }^{\text {b) }}$} & \multirow{2}{*}{ Dilution } & \multirow{2}{*}{$\begin{array}{l}\text { TMPMA } \\
(\mathrm{mol} \%)\end{array}$} & \multirow{2}{*}{$\begin{array}{c}\text { Gel point } \\
(\%)\end{array}$} & \multirow{2}{*}{$\bar{P}_{w, 0} \times 10^{-3}$} & \multirow{2}{*}{$\begin{array}{c}\text { Actual G.P. } \\
\text { Theoretical G.P }\end{array}$} \\
\hline & & & & & \\
\hline DOx & $1 / 3$ & 0.5 & 16.0 & 4.62 & 7.3 \\
\hline BuAc & $1 / 3$ & 0.5 & 14.5 & 3.55 & 5.1 \\
\hline DOx & $1 / 5$ & 0.5 & 32.5 & 2.84 & 9.1 \\
\hline BuAc & $1 / 5$ & 0.5 & 41.0 & 2.46 & 10.0 \\
\hline DOx & $1 / 5$ & 1 & 21.0 & 4.27 & 17.6 \\
\hline BuAc & $1 / 5$ & 1 & 24.0 & 2.41 & 11.3 \\
\hline DOx & $1 / 8$ & 1.5 & 36.5 & 3.95 & 42.0 \\
\hline BuAc & $1 / 8$ & 1.5 & 66.0 & 2.55 & 49.0 \\
\hline DOx & $1 / 8$ & 5 & 22.5 & 7.92 & 162 \\
\hline BuAc & $1 / 8$ & 5 & 33.0 & 3.52 & 106 \\
\hline
\end{tabular}

a) $[\mathrm{AIBN}]=0.04 \mathrm{~mol} / \mathrm{l}, 50^{\circ} \mathrm{C}$.

b) DOx, 1,4-dioxane; BuAc, $n$-butyl acetate.

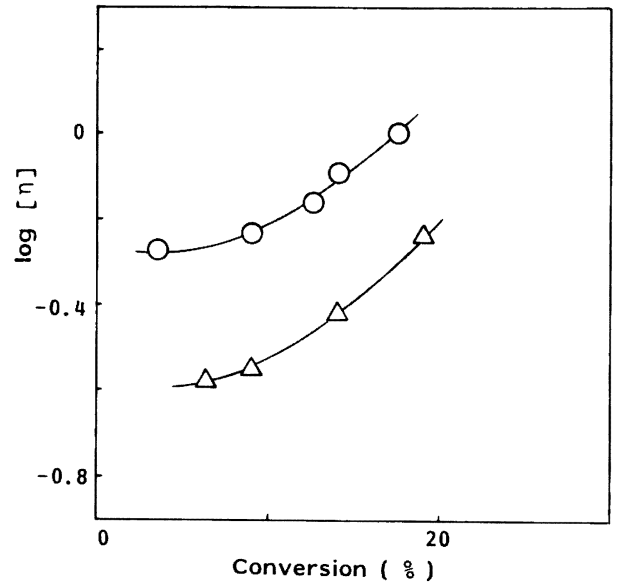

Fig. 3. Dependence of $[\eta]$ on conversion in the MMA-TMPMA $(99: 1)$ copolymerization in 1,4 dioxane $(O)$ and $n$-butyl acetate $(\triangle)$. Polymerization conditions were the same as those in Fig. 1.

で, 理論ゲル化点を求め, 実測ゲル化点との比較を次に 試みた。なお, 理論ゲル化点の算出に当たっては Stockmayer $の$ 式 ${ }^{37)}: \alpha_{\mathrm{c}}=1 / \rho\left(\bar{P}_{\mathrm{w}, 0}-1\right)$ を近似的に用いた。ここ で $\rho$ としては, TMPMA が上述のようにジビニルモ, マ一類似の挙動を示すところから2[TMPMA]/ \{[MMA]+3[TMPMA]\} として求め, $\bar{P}_{w, 0}$ は, MMA と TMPMA の 1 個のビニル基の反応性が等しい仮定して 求めたコポリマー組成と $\bar{M}_{w, 0}$ から算出した.

\section{4 ゲル化点の理論値と実測值の比較}

前項で述べたようにして理論ゲル化点を算出し，実測 値との比較を Table 1 にまとめた. いずれの系において
あ実測値は理論値に比して大きく高重合率側へとずれて おり, 高希釈, 高 TMPMA 含量系ほどそのずれは拡大し た. 特に, DOx 中, 1/8 希釈, TMPMA 含量 $5 \mathrm{~mol} \%$ の 系では実測ゲル化点は理論值の 162 倍にも達した。

一方，良溶媒である DOx 中之貧溶媒である BuAc 中 でのゲル化点の理論値からのずれを比較してみると, $1 / 3$ 希釈 : TMPMA $0.5 \mathrm{~mol} \%$ 系, $1 / 5: 1 \mathrm{~mol} \%$ 系, 及び $1 / 8: 5 \mathrm{~mol} \%$ 系では，これまでの結果と同様，良溶媒中 でゲル化の遅延が認められた。 それに対して，1/5:0.5 mol\% 系及び 1/8 : $1.5 \mathrm{~mol} \%$ 系では興味深いことにわず かながら貧溶媒中の方がゲル化点の理論値からのずれは 拡大した。 すなわち，希釈度が低いとき，あるいは橋か け剂含量の高いときには良溶媒中のゲル化が遅延するの に対し，高希釈系で橋かけ剤が比較的少ないときには貧 溶媒中の方がゲル化が遅延するといえる．このような結 果は分子内橋加け反応の生起と関連しているものと推察 される.すなわち，モノビニルーポリビニル共重合系にお いては重合の進行とともに分子橋加け反応の生起が活発 化することが知られており1),36), 分溶媒中の方がポリ マー鎖のコイリングが密なため良溶媒中よりも分子内橋 かけ反応が起こりやすくなっていることが考えられる. 分子内橋かけ反応の生起はポリマーの粘度に反映される ところから, 次に極限粘度の測定を試みた。

\section{5 分子内橋かけ反応における溶媒効果}

Fig. 3 は生成ポリマーの極限粘度の重合率依存性の一 例を示したすのである．分溶媒である BuAc 中で生成し たポリマーの極限粘度はかなり大きく低下しているのが わかる. しかしながら，Fig. 2 に見られるように分子量 も低下しているところから，粘度の低下が分子内橋かけ 反応の生起に基づくあのか, 分子量の低下によるかは定 かではない，そこで, 分子内橋かけ反応がより活発化し, 
メチルメタクリレートートリメチロールプロパントリメタクリレート共重合系のゲル化における溶媒効果

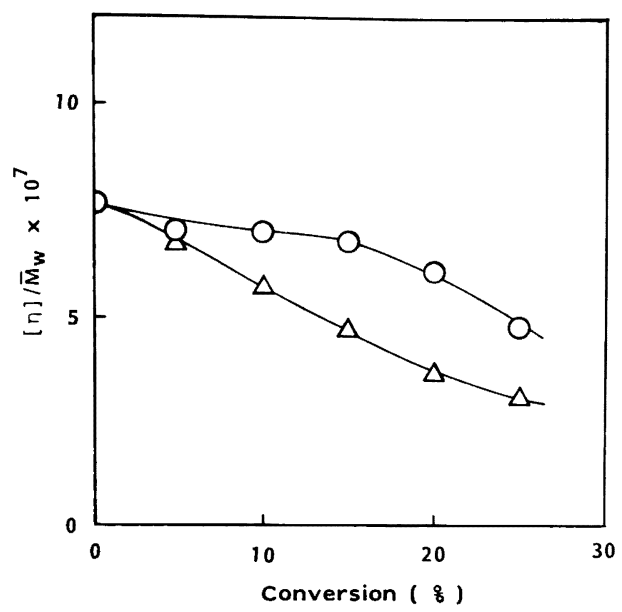

Fig. 4. Dependence of $[\eta] / \bar{M}_{w}$ on conversion in the MMA-TMPMA $(98.5: 1.5)$ copolymerization in 1,4 dioxane $(O)$ and $n$-butyl acetate $(\triangle)$. Polymerizations were conducted in a dilution of $1 / 8$ using $0.04 \mathrm{~mol} / l$ of AIBN at $50^{\circ} \mathrm{C}$.

かつ負溶媒中でゲル化の遅延が認められた $1 / 8$ 希釈： TMPMA $1.5 \mathrm{~mol} \%$ 系について, 生成ポリマーの極限粘 度と分子量の相関を詳しく調べた. Fig. 4 から明らかな ように，予想どおり資溶媒である BuAc 中の方が分子量 に対する極限粘度の低下が顕著であった。

以上の結果から, 前項で示したゲル化点の実測値の理 論値からのずれに対する溶媒効果, すなわち高希釈系で 橋かけ剤が比较的少ないときには負溶媒中の方がゲル化 が婵延する点については, 次のように理解される. 貧溶 媒中では分子内橋かけ反応が重要であり, 高希釈系でよ り重要になるところから, TMPMA 含量の少ない系では 分子内橋かけ反応を十分に行うだけのペンダントビニル 基がプレポリマー中に存在し得なくなり,たとえ良溶媒 中でポリマー銷の相互侵入が自由となり, 分子間橋かけ 反応の生起する確率が高い状況下でさえゲル化が遅延し たものと推察される.したがって，1/8 希釈系でも TMPMA 含量を $5 \mathrm{~mol} \%$ と高くすると, プレポリマー中 にはペンタントビニル基が十分に存在するところから貣 溶媒中での分子間橋かけ反応が活発化し, 逆に良溶媒中 でゲル化が大きく遅延したものと考えられる.

このような考察は生成ゲルの膨潤比測定の結果 (Fig. 5)ともよく対応している，すなわち，全般的に負溶媒中 で得られたゲルの方が大きな膨潤比を示しており，特に 芧溶媒中でゲル化の遅延した系ではその差異は大きく， ペンタントビニル基の不足を反映しているものと推察さ れる.

最後に, 先にも少し触れた一次ポリマー鎖中の大環状

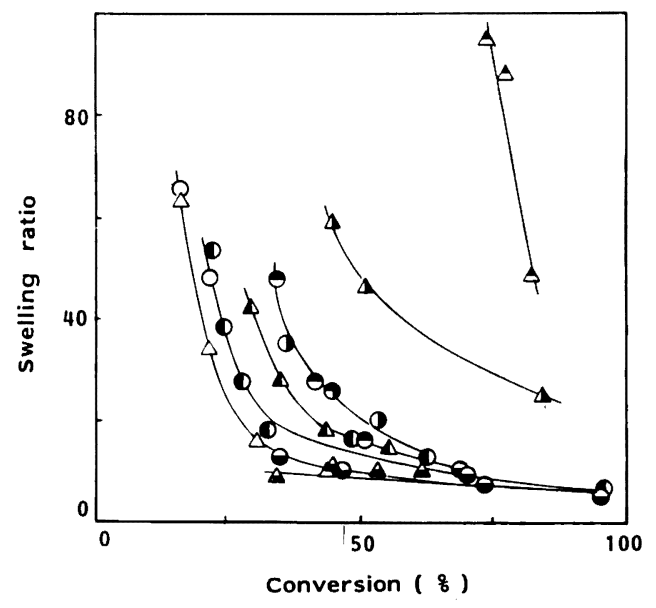

Fig. 5. Dependence of the swelling ratio of the resulting gel on conversion. Polymerization conditions were as follows: dilution, TMPMA mol\%; 1/3, $0.5(\bigcirc, \triangle)$; $1 / 5,0.5(\circlearrowleft, \Delta) ; 1 / 5,1(\odot, \Delta) ; 1 / 8,1.5(\Theta, \Delta) ; 1 / 8$, $5(\Theta, \Delta)$. Circles or triangles correspond to the gels obtained in 1,4-dioxane or $n$-butyl acetate, respectively.

構造の形成に及ぼす溶媒の影響について若干の考察を 行った.

3.6 一次ポリマー鎖中の大環状搆造形成における溶 媒効果

モノピニルーポリビニル共重合系で生成する初期ポリ マ-（分子間橋かけ反応が無視できる）中には, 生長ラ ジカルと生長鎖中のペンダントビニル基との間での分子 内環化反応によって形成された大環状構造が存在するこ とがよく知られている゙，著者らはこのような大環状構 造の形成を次のようにして評価した ${ }^{38)}$.すなわち，1）分 子量の重合率依存性（Fig. 2 参照）から重合率ゼロに外 挿することによって, 分子間橋かけ反応が無視できる重 合初期段階で生成する初期ポリマーの分子量 $\bar{M}_{\mathrm{w}, 0}$ を求 める．2）初期ポリマーが直銷状であると仮定して $\bar{M}_{\mathbf{w}, 0}$ から $[\eta]_{\mathrm{L}}$ を算出する。本研究では TMPMA 含量が少な いところから、MMA ホモポリマーから求めた $[\eta]_{\mathbf{L}}=$ $4.24 \times 10^{-5} \bar{M}_{* 0}^{76}$ を用いた。 3) 極限粘度の重合率依存性 (Fig. 3 参照) から重合率ゼロに外挿することによって初 期ポリマーの $[\eta]_{0}$ を求める. 4) $[\eta]_{0} /[\eta]_{\mathrm{L}}$ は初期ポリ マーの直鎖性を議論する上での尺度となり, $[\eta]_{0} /[\eta]_{\mathbf{L}}=$ 1 であれば直鎖ポリマーと考えられるが，大環状構造が 形成成されると1より小さくなる。

Table 2 に得られた結果をまとめた，いずれの場合む $[\eta]_{0} /[\eta]_{\mathrm{L}}$ は 1 より小さくなっており, 高希釈系ほど低 下した. これは大環状構造の形成を伴う分子内環化反応 が一分子反応であることを考慮するとよく理解される。 
松本・安藤・大岩

Table 2. Deviation of primary chain from linearity

\begin{tabular}{lccccc}
\hline \hline Solvent( & Dilution & $\begin{array}{c}\text { TMPMA } \\
(\mathrm{mol} \%)\end{array}$ & $\bar{M}_{\mathrm{w}, 0} \times 10^{-5}$ & $\begin{array}{c}{[\eta]_{0}} \\
(\mathrm{~d} l / \mathrm{g})\end{array}$ & {$[\eta]_{\mathrm{o}} /[\eta]_{\mathrm{L}}{ }^{\mathrm{b})}$} \\
\hline DOx & $1 / 3$ & 0.5 & 4.79 & 0.69 & 0.78 \\
BuAc & $1 / 3$ & 0.5 & 3.68 & 0.52 & 0.73 \\
DOx & $1 / 5$ & 0.5 & 2.94 & 0.41 & 0.68 \\
BuAc & $1 / 5$ & 0.5 & 2.55 & 0.30 & 0.56 \\
DOx & $1 / 5$ & 1 & 4.57 & 0.54 & 0.64 \\
BuAc & $1 / 5$ & 1 & 2.58 & 0.24 & 0.44 \\
DOx & $1 / 8$ & 1.5 & 4.37 & 0.43 & 0.44 \\
BuAc & $1 / 8$ & 1.5 & 2.82 & 0.21 & 0.36 \\
\hline
\end{tabular}

-) DOx, 1,4-dioxane; BuAc, $n$-butyl acetate.

b) $[\eta]_{\mathrm{L}}=4.24 \times 10^{-5} \bar{M}_{m, 0}^{0.76}$.

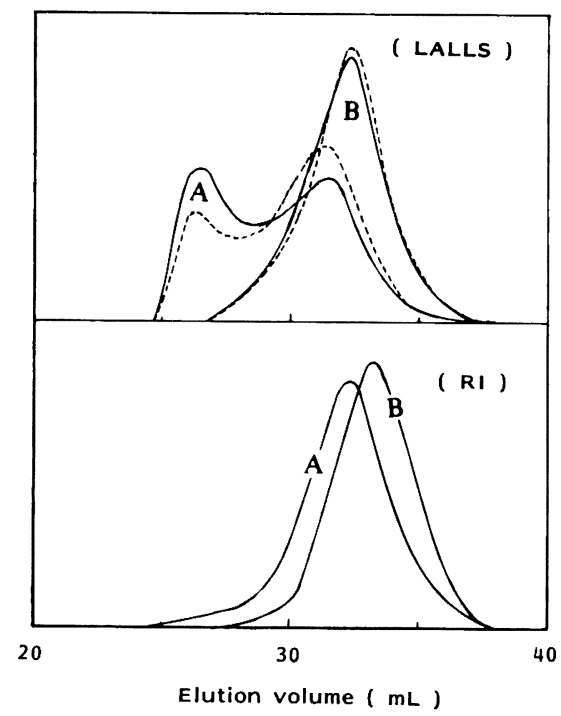

Fig. 6. GPC-LALLS curves of the copolymers obtained in 1,4-dioxane (A) and $n$-butyl acetate (B). Polymerization conditions were the same as those in Fig. 4 and conversions were $c a .4 \%$. Dotted lines were calculated from RI-monitored curves.

また，芧溶媒である BuAc 中の方が大環状構造の形成か 促進されていることがうかがえる。これはポリマー鎖の コイリングが貧溶媒中ほど密であることによるものと思 われる.

ところで，初期ポリマーの分子量 $\bar{M}_{\mathrm{w}, 0}$ は明らかに良 溶媒であるDOx 中で大きくなっているのがわかる．こ れと同様の結果は MMA とオリゴグリコールジメタク リレートの共重合 ${ }^{35)}$ においても観測されている. 良溶媒 中では, 生長ラジカルがいったん大環状構造の形成を伴 う分子内環化反応を行った際には，そのようなポリマー ラジカル間の停止反応は, セグメント拡散の抑制,さら
には排除体積効果（高分子量化するにつれこの寄与が大 きくなると考えられる）のために起こりにくくなり，生 成ポリマー中に一部大きく高分子量化したポリマーが含 まれるようになるものと推察される ${ }^{38}$. 一一方, 貣溶媒中 では分子間の相互侵入が自由であり，排除体積効果の寄 与もなく, 上記のような意味合いでの高分子量化は生起 しにくいものと考えられる. Fig. 6 は $1 / 8$ 希釈: TMPMA 含量 $1.5 \mathrm{~mol} \%$ 系で得られた重合率約 4\%のポ リマーのGPC-LALLS 曲線を示したものである.

LALLS 曲線において点線で示したのは直鎖ポリマーを 仮定して RI 曲線から求めたものであり, 実線が点線よ り高分子量側にずれているのは高分子量ポリマー中に大 環状構造がより多く存在していることを示唆している. 洏溶媒である BuAc 中では実線の点線からのずれはほん のわずかであるのに対し，良溶媒であるDOx中では顕 著なずれが認められた．このような GPC-LALLS 測定 の結果は上述の考察を支持するものである.

\section{文献}

1) 松本 昭, 大岩正芳、高分子, 34, 200 (1985).

2) B. T. Storey, J. Polym. Sci., A3, 265 (1965).

3) J. Malinsky, J. Klaban, and K. Dusek, J. Macromol. Sci.Chem., A5, 1071 (1971).

4) B. Soper, R. N. Haward, and E. F. T. White, J. Polym. Sci, A-1, 10, 2545 (1972).

5) P. W. Kwant, J. Polym. Sci., Polym. Chem. Ed., 17, 1331 (1979).

6) R. Okasha, G. Hild, and P. Rempp, Eur. Polym. J., 15, 975 (1979).

7) R. Leicht and J. Fuhrmann, Polym. Bull., 4, 141 (1981).

8) J. K. Fink, J. Polym. Sci., Polym. Chem. Ed., 18, 195 (1981).

9) G. Hild and P. Rempp, Pure Appl. Chem., 53, 1541 (1981).

10) G. Hild and R. Okasha, Makromol. Chem., 186, 93 (1985).

11) C. Walling, J. Am. Chem. Soc., 67, 441 (1945).

12) M. Gordon and R.-J. Roe, J. Polym. Sci., 21, 27, 39, 75 (1956). 
13) J. Jokl, J. Kopecek, and D. Lim, J. Polym. Sci, A-1, 6, 3041 (1968).

14) K. Horie, A. Otagawa, M. Muraoka, and I. Mita, J. Polym. Sci., Polym. Chem. Ed., 13, 445 (1975).

15) H. Galina, K. Dusek, Z. Tuzar, M. Bohdanecky, and J. Sokr, Eur. Polym. J., 16, 1043 (1980).

16) J. Spevacek and K. Dusek, J. Polym. Sci., Polym. Phys. Ed., 18, 2027 (1980).

17) K. Dusek and J. Spevacek, Polymer, 21, 750 (1980).

18) R. S. Whitney and W. Burchard, Makromol. Chem., 181, 869 (1980).

19) A. C. Shah, I. W. Parsons, and R. N. Haward, Polymer, 21, 825 (1980).

20) G. Hild and R. Okasha, Makromol. Chem., 186, 389 (1985).

21) A. Matsumoto, H. Matsuo, and M. Oiwa, Makromol. Chem., Rapid Commun., 8, 373 (1987).

22) W. Simpson T. Holt, and R. J. Zetie, J. Polym Sci., 10, 489 (1953).

23) M. Gordon, J. Chem. Phys., 22, 610 (1954).

24) W. Simpson and T. Holt, J. Polym. Sci., 18, 335 (1955).

25) 大岩正芳, 尾形弥生, 日本化学会誌, 79, 1506 (1958).

26) A. Matsumoto, S. Yokoyama, T. Khono, and M. Oiwa, $J$. Polym. Sci., Polym. Phys. Ed., 15, 127 (1977)

27) A. Matsumoto, Y. Ogasawara, S. Nishikawa, T. Aso, and M
Oiwa, J. Polym. Sci., A, Polym. Chem., 27, 839 (1989).

28) A. Matsumoto, S. Ohtsuka, Y. Ohara, and M. Oiwa, Polym. Prepr. Am. Chem. Soc., Div. Polym. Chem., 20(1), 921 (1979).

29) K. Honda, A. Matsumoto, and M. Oiwa, Polym. Prepr. Jpn., 30(5), 916 (1981).

30) A. Matsumoto and M. Oiwa, 3rd Japan-China Symp. on Radical Polymerization, August 1984, p. 29.

31）松本 昭，中島秀幸，大岩正芳，熱硬化性樹脂，9，141 (1988).

32) H. Morawetz, J. R. Cho, and P. J. Gans, Macromolecules, 6, 624 (1973).

33) A. Matsumoto, S. Ohtsuka, Y. Hirota, Y. Ohara, and M. Oiwa, Polym. Prepr. Jpn., 27(6), 1060 (1978).

34) 松本 昭, 角 英行, 大岩正芳, 第 32 回熱硬化性樹脂講 演討論会講演要旨集 (1982), p. 96.

35) A. Matsumoto, H. Matsuo, H. Ando, and M. Oiwa, Eur. Polym. J., 25, 237 (1989).

36) A. Matsumoto, H. Ando, and M. Oiwa, Eur. Polym. J., 25, 385 (1989).

37) W. H. Stockmayer, J. Chem. Phys., 12, 125 (1944)

38) A. Matsumoto, H. Matsuo, and M. Oiwa, J. Polym. Sci., C. Polym. Lett., 26, 287 (1988).

Solvent Effect on the Gelation in the Copolymerization of Methyl Methacrylate with Trimethylolpropane Trimethacrylate

Akira Matsumoto*1, Hiroyuki ANDo*1, and Masayoshi OrwA*1

*1 Department of Applied Chemistry, Faculty of Engineering, Kansai University (Suita, Osaka, 564 Japan)

Methyl methacrylate was radically copolymerized with trimethylolpropane trimethacrylate (TMPMA) using dioxane or $n$-butyl acetate as a good or poor solvent, respectively, and the solvent effect on the gelation is explored in detail. The delay between the actual gel point and the theoretical one was usually larger in dioxane, suggesting a significance of the excluded volume effect on the intermolecular crosslinking reaction. On the other hand, the delay of the actual gel point from the theoretical one was larger in $n$-butyl acetate for the copolymerization in high dilution with a small amount of TMPMA; this may be ascribed to a quite reduced amount of pendant vinyl groups, responsible for crosslinking, in the prepolymer as a reflection of the enhanced occurrence of intramolecular crosslinking. The loop structure through intramolecular cyclization in the primary chain was formed to a larger extent in $n$-butyl acetate.

KEY WORDS Methyl Methacrylate / Trimethylolpropane Trimethacrylate / Gelation / Solvent Effect /

Copolymerization / Crosslinking /Cyclization / Excluded Volume Effect /

(Received May 30, 1989: Accepted July 3, 1989)

[Kobunshi Ronbunshu, 46(10), 583-589 (1989)] 